\title{
居宅介護支援につながる老人短 A STUDY ON THE WAY FORWARD OF 期入所施設のあり方に関する一 RESPITE CARE FACILITIES FOR 考察 SUPPORTING CARE AT HOME
}

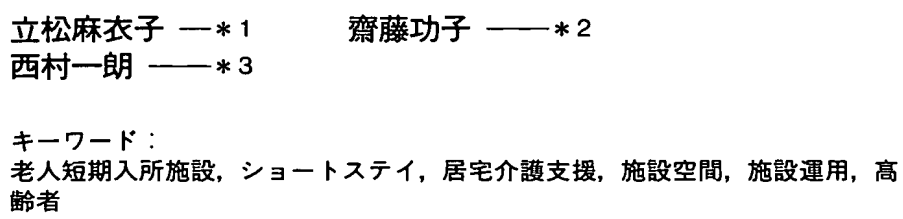

Respite care facilities for the elderly, Respite care, Suppout for care at home, Space in facility, Facility management, The elderly
Maiko TATEMATSU $-* 1$
Ichiro NISHIMURA $-* 3$

Noriko SAITO $-* 2$

This paper aims to examine the care for users and the way forward of respite care facilities for the elderly. The findings are as follows. (1) An individual interview is necessary for users in advance, in order to grasp users' accurate conditions. (2) It is necessary for users to rearrange rooms for individual comfortable environment for reducing stresses by relocation, the smaller inside spaces, and arranging safe outside spaces. (3) It is important for users to provide occasions for improving ADL and social life. (4) Staffs for respite care need to widen knowledge of environmental preparation at users' houses. (5) The space for only respite care users enables to treat individually by considering both services and space in facility.

\section{1.はじめに}

\section{1 調査の背景}

短期入所サービスは自宅で介護を受けている要援護高龄者が、短 期間施設に入所するサービスで、一般にショートスティ（以下、シ ヨートステイと表記する）ともいわれている。現行のショートステ イには介護保険制度により「短期入所生活介護」と「短期入所療養 介護」の 2 種類があり、ともに介護をしている家族が何らかの理由 で家を空ける必要があるとき、介護疲れからのリフレッシュをはか りたいときなどに利用し、利用する際の理由については問われてい ない。利用期間については、利用者の要介護度ごとに使える日数の 上限が定められているが、訪問系・通所系サービスの利用が一定割 合以下の人を対象に短期入所の日数を増やすことも可能である ${ }^{1)}$

ショートステイは、デイサービス、ホームヘルブサービスと併せ て居宅介護を支援するサービスの一つとして重視されてきた。しか しショートステイは、短期間であるが要援護高齢者の生活拠点が自 宅から施設に移動するという点でデイサービスやホームヘルプサー ビスとは異なる側面をもっている。またショートステイは、施設内 でサービスが提供されるが、入所期間が短いことや、対象者がふだ んは自宅で生活を営んでいる要援護高齢者であるという点で特別養 護老人ホーム等の施設サービスとも異なる側面をもっている。

近年の高齢者居住施設の空間計画における先行研究としては、齋 藤らは車イスでの移動を中心とした環境のあり方を入居者の視点か ら捉え、施設睘境のあり方について考察している2)。また林らは特 別養護老人ホームの個の空間の住まい方に影響を及ぼす条件の違い による実態と問題点を捉え、個室空間の最適条件を明らかにしろ)、
井上らは特別養護老人ホームにおける個室と共用空間の必要性と施 設整備が個別介護に与える影響について明らかにしている ${ }^{4) 。 さ ら ~}$ に個室型特別養護老人ホームの空間構成について、橎らは共用空間 の役割と意味を明らかにし施設の空間構成のあり方を考察し5)、山 田らは入所者の生活行動と場との関わり方や共用空間で展開される 生活行動と場の関わりを把握し、共用空間の計画デザインに一定の 示唆を与えている6)。またリロケーションによる生活環境の変化に ついて、渡邊らは特別養護老人ホームの共用空間に生活感をもたせ るような活気・落ち着きのメリハリの効いた空間にしてくための計 画手法の確立を行い7)、足立らは環境移行が入所者の行動にどのよ うな影響を及ぼすかについて、行動・性格両面からみた環境移行時 の特性を明らかにしている8⿱。グループホームに関しては、石井ら

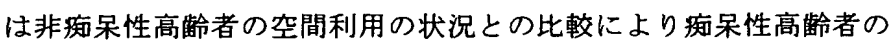
空間利用の特性を明らかにし、居室と共用空間の意味を示唆し9)、 鈴木らは生活環境の移行による入居者の生活・ケア内容の変化を時 系列的に調査・分析し、グループホームの質的側面とその有效性を 明らかにし、グループホームおよび大規模高齢者居住施設の設計 · 計画に対して示唆を与えている ${ }^{10)}$ 。

このように施設空間計画について特別養護老人ホームやグルー プホームを中心に様々な視点から数多くの研究の積み重ねがあり、 各々が施設空間に対して有効かつ重要な示唆を与えている。しかし 施設を生活の場と位置付けて考えるにあたっては調查対象を長期入 所者に限定して考察する必要があり、短期間の利用ゆえ施設環境に なれていないショートステイ利用者（以下、利用者と表記する）に ついては省いて考察されており、ショートステイための施設空間の

* 1 Graduate Student, Doctor's Degree Course, Faculty of Human and Culture, Nara Women's University., M.R.E.

*2 Assoc. Prof., Ikenobo College, Ph. D.

*3 Prof., Dept. of Residential Environment, Nara Women's University, Dr. Eng. 
考察について十分な蓄積があるとはいえない。利用者の生活拠点は 自宅であること、施設利用による影響は利用者の居宅生活および居 宅介護を左右することから ${ }^{11)}$ 、施設空間計画に関して、長期入所者 とショートステイ利用者とは異なる視点からの考察が必要であると 考える。

\section{2 調查の目的}

本研究は、ショートステイの利用主体である要援護高路者の生活 拠点は自宅であり、ショートステイは居宅介護の延長としてのサー ビスであるという観点に立って、ショートスティがどうあるべきか を考えようとするものである。

著者らは特別養護老人ホーム（以下、特養と表記する）における ショートステイを対象にショートステイのために使われている居室 の類型から 3 つ居室タイプを明らかにし、居室タイプ別の設置理 由、利用居室、居室配置、利用者へのケア内容、職員の業務内容等 を把握し、特養におけるショートステイのための居室計画を検討し ている ${ }^{12)}$ 。また、ショートステイのみを入所対象とする老人短期入 所施設（ショートステイ専用施設）を対象に、施設開設経歴や関連 施設との立地関係、利用居室等の実態把握を行なうとともに、長期 入所者とショートステイ利用者が混在する特養と、老人短期入所施 設それぞれのショートステイを居室や職員業務等に関して比較する ことで、老人短期入所施設の実態を把握している ${ }^{13)}$ 。

本論は、一連の調查研究の続きとして、ショートステイのみを入 所対象とする老人短期入所施設（ショートステイ専用施設）を対象 に、利用者の日中の居場所や施設生活、施設側の利用者への対応等 を把握することでショートステイ利用者のみの空間で展開されるケ アの実態を把握し、居宅介護を支援する老人短期入所施設のあり方 を検討する。

なお、家族介護者およびショートステイ利用者の属性や利用理由、 利用による効果等については既に調查・分析し、利用側のショート ステイの意義に関する一知見を得ている ${ }^{11)} 14$ )。

\section{2. 調査方法}

老人短期入所施設（以下、短期入所施設と表記する）の赛態を把 握するために、全国の短期入所施設全 130 施設（2000 年 12 月調査 時点）を対象とした郵送調查を行なった。調查内容は施設の概要、 施設空間、利用者へのケア内容、家族・地域について等である。之 の結果 60 施設より回答を得ることができた。そのうち既に特養に転 換している施設が 2 施設、短期入所施設が特養に併設しており、特 盖の空きベッドを利用してショートステイを受け入れている施設が 1 施設あった。本論では、60 施設のうちこの 3 施設を除いた 57 施 設を分析対象とする。

\section{3. 分析対象施設の概要}

分析対象施設の概要と開設経歴を表 1 に示す。なお、対象施設の 概要や開設経歴、利用居室に関しては既に詳細に報告しているが ${ }^{13)} 、$ 同 57 施設を対象として本報告を展開するため再度簡潔に記す。

\section{1 施設開設年とショートステイ定員}

分析対象 57 施設では、ショートステイ定員は最小 20 人から最大 50 人であり、定員 30 人の施設が 27 施設あり最も多い。また定員 20 人の施設は 18 施設あり、そのうち 16 施設は 1999 年以降に開設され
表 1. 分析対象施設の概要と開設経歴

\begin{tabular}{|c|c|c|c|c|c|c|c|c|}
\hline $\mathrm{Na}$ & 施般閶設年 & 定员 & 施祋類型 & 類型辡細 & 個室 & & & 四人 \\
\hline 1 & 1975年（1999） & 30 & D併段 & SD & 3 & 3 & 3 & 2 \\
\hline 2 & 1976年(1998) & 20 & D併設 & SD+特 & $\overline{0}$ & 7 & 2 & $\overline{0}$ \\
\hline 3 & 1983年(1995) & 30 & D併役 & $S D+$ 特 & 4 & 5 & 0 & 2 \\
\hline 4 & 1986年(1993) & 50 & S単独 & $S+$ 特D & 0 & 11 & 0 & 7 \\
\hline 5 & 1986年(1996) & 30 & S単独 & $S+$ 特D & 14 & 8 & 0 & 0 \\
\hline 6 & 1986年(1997) & 30 & 特婁併融 & S特D & 0 & 1 & 0 & 7 \\
\hline 7 & 1989年(1996) & 30 & D併設 & SD+特 & 4 & 1 & 0 & 6 \\
\hline 8 & 1993年 & 50 & S単独 & $s$ & 1 & 1 & 0 & 11 \\
\hline 9 & 1993年(1998) & 30 & S単独 & $S+$ 特D & 8 & $\overline{11}$ & 0 & 0 \\
\hline 10 & 1993年 & 20 & D併設 & SD & 16 & 2 & 0 & 0 \\
\hline 11 & 1995年 & 40 & 特美併設 & $S$ 特 $+D$ & 2 & 1 & 0 & 9 \\
\hline 12 & 1995年 & 30 & D併設 & SD & 0 & 8 & 2 & 2 \\
\hline 13 & 1996年 & 40 & 特银併設 & S特D & 0 & 8 & 0 & 6 \\
\hline 14 & 1996年 & 30 & 特赛併設 & S特D & 0 & 3 & 0 & 6 \\
\hline 15 & 1996年 & 30 & 特垩併設 & S特D & 4 & 1 & 0 & 6 \\
\hline 16 & 1996年 & 30 & 特害併設 & S特D & 26 & 2 & 0 & 0 \\
\hline 17 & 1996年 & 30 & 特亚併設 & S特D & 18 & 2 & 0 & 2 \\
\hline 18 & 1997年 & 30 & D併設 & SD & 1 & 2 & 2 & 5 \\
\hline 19 & 1997年 & 30 & 特寒併設 & S特D & 4 & 13 & 0 & 0 \\
\hline 20 & 1997年 & 30 & 特美併飘 & S特D & 10 & 10 & 0 & $\overline{0}$ \\
\hline 21 & 1998年 & 50 & D併設 & SD & 0 & 6 & 2 & 8 \\
\hline 22 & 1998年 & 30 & D併設 & SD & * & * & * & * \\
\hline 23 & 1998年 & 30 & D併設 & $S D$ & 12 & 1 & 0 & 4 \\
\hline 24 & 1998年 & 30 & D併設 & SD & 2 & 0 & $\mathbf{0}$ & 7 \\
\hline 25 & 1998年 & 30 & D併設 & SD+特 & 10 & 4 & 0 & 3 \\
\hline 26 & 1998年 & 30 & D併設 & SD & 0 & 15 & 0 & 0 \\
\hline 27 & 1998年 & 30 & D併設 & SD & 30 & 0 & 0 & 0 \\
\hline 28 & 1999年 & 50 & S単独 & $\mathrm{s}$ & 6 & 0 & 0 & 11 \\
\hline 29 & 1999年 & 50 & S単独 & $s$ & 8 & 21 & 0 & 0 \\
\hline 30 & 1999年 & 40 & S単独 & $s$ & 10 & 11 & 0 & 2 \\
\hline 31 & 1999年 & 30 & D併設 & SD & 4 & 11 & 0 & 1 \\
\hline 32 & 1999年 & 30 & D併設 & SD & 30 & 0 & 0 & 0 \\
\hline 33 & 1999年 & 30 & D併設 & SD & 2 & 2 & 0 & 6 \\
\hline 34 & 1999年 & 30 & 特意併設 & S特D & 30 & 0 & 0 & $\begin{array}{l}0 \\
0\end{array}$ \\
\hline 35 & 1999年 & 30 & 特黄併設 & S特D & 6 & 0 & 0 & 6 \\
\hline 36 & 1999年 & 21 & D併没 & SD & 7 & 7 & 0 & 0 \\
\hline 37 & 1999年 & 20 & D併設 & SD & 0 & 2 & 0 & 4 \\
\hline 38 & 1999年 & 20 & D併設 & SD & 20 & 0 & 0 & 0 \\
\hline 39 & 1999年 & 20 & D併設 & SD & 10 & 1 & 0 & 2 \\
\hline 40 & 1999年 & 20 & 特赛併殿 & S特D & 0 & 0 & 0 & 5 \\
\hline 41 & 2000年 & 40 & S単独 & $s$ & 14 & 13 & 0 & 0 \\
\hline 42 & 2000年 & 30 & D併設 & SD & 14 & 4 & 0 & 2 \\
\hline 43 & 2000 年 & 30 & D併設 & SD & 20 & 5 & 0 & 0 \\
\hline 44 & 2000年 & 23 & D併設 & SD & 11 & 3 & 2 & 0 \\
\hline 45 & 2000年 & 21 & 特善併設 & S特D & 19 & $\overline{1}$ & 0 & 0 \\
\hline 46 & 2000年 & 20 & S単独 & $s$ & 0 & 2 & 4 & 1 \\
\hline 47 & 2000年 & 20 & D併設 & SD & 4 & 4 & 0 & 2 \\
\hline 48 & 2000年 & 20 & D併役 & SD & 8 & 6 & 0 & 0 \\
\hline 49 & 2000年 & 20 & D併設 & SD & 20 & 0 & 0 & 0 \\
\hline 50 & 2000年 & 20 & D并設 & SD & 8 & 4 & 0 & 1 \\
\hline 51 & 2000年 & 20 & D併設 & SD & 1 & 0 & 1 & 4 \\
\hline 52 & 2000年 & 20 & D併設 & SD & 12 & 0 & 0 & 2 \\
\hline 53 & 2000年 & 20 & D併設 & SD & 0 & 10 & 0 & 0 \\
\hline 54 & 2000年 & 20 & D併設 & SD & 12 & 4 & 0 & 0 \\
\hline 55 & 2000年 & 20 & D併設 & $\mathrm{SD}$ & 16 & 2 & 0 & 0 \\
\hline 56 & 2000年 & 20 & 特贯併設 & $S$ 特D & 8 & 2 & 0 & 2 \\
\hline 57 & 2000年 & 20 & 特坥伴設 & S特D & 0 & 6 & 0 & 2 \\
\hline
\end{tabular}

・開設年」の（）内は、開設当初は特巻の曹莱のーつとしてショートステイを行って いたがショートステイのみを独立して行うようになつた施設で、施設開設年と老人短

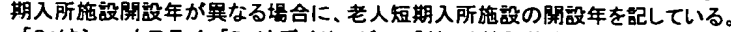

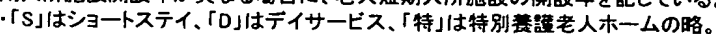

・利用居室」は、各施設で利用している各居室の利用数を趾している

・「*」は回答の得られなかったものについて蚛している。
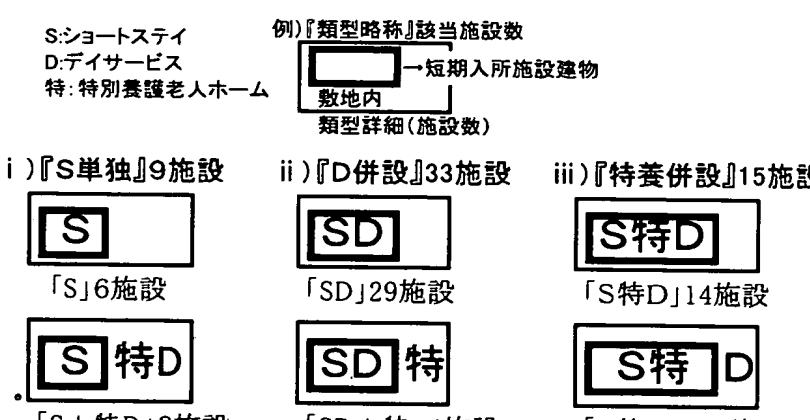

「S+特D」3施設
「S特 $+\mathrm{D}\lrcorner 1$ 施設

図1．関連事業からみた立地関係 
ており、その他 2 施設は 1976 年（施設No.2）と 1993 年（施設No.10） に開設されている。1976 年開設の施設（№.2）は1998 年に短期入 所施設を新たに開設し、特羡の空きベッドを利用する形態から 20 人定員の短期入所施設に変更している。また 1993 年開設の施設 (No. 10）は1999年に施設を增築して定員を 4 人から 20 人に変更してい る。このことから短期入所施設の定員は 30 人が最も多いが、定員が 20 人の施設は 1999 年以降に開設された新しい施設が大半を占める ことがわかる。

\section{2 関連事莱との立地関俰}

短期入所施設は、同一建物にある要援護高龄者を対象とした事業 から次の 3 つに分類できる（図 1)。一つは、同一建物内で実施して いる事業がショートステイのみである場合である (『S 単独』)。この 型には敨地内に特養とデイサービスの建物がある場合（「S+特D」） も含む。二つは、同一建物内で実施している事業にショートステイ とデイサービスがある場合である(『D併設』)。この型には敖地内に 特養の建物がある場合（「SD+特」）も含む。三つは、同一建物内で 実施している事業にショートステイと特養がある場合である(『特養 併設』)。この型は建物内にデイサービスがある場合（「S 特 DJ）と、 敷地内にデイサービスの建物がある場合（「S 特+DJ）である。

教地内に短期入所施設のみがある 6 施設以外は、同一建物内また は晋地内にデイサービスがあり、在宅サービス間での連携が取りや すく、また情報が共有しやすい立地関係にある。

\section{3 利用居室}

短期入所施設で利用者のために使われている居室は、個室〜四人 部屋が使われており、利用居坔の種類や数は施設によって異なる。 利用者に対して個室のみを利用している施設は 4 施設である。

施設開設年の新しい施設では個室や二人部屋中心の施設が増加 傾向にあるが、利用者の生活拠点は自宅であり、ショートステイを 利用することで転居のストレスが生じる可能性があることを考慮す ると、短期入所施設においてはより一層の個室整備が必要であると 考えられる。また定員規模が大きい施設は四人部屋の利用が多くな る傾向があり、間仕切りや部屋割り、共用空間等個々の利用者のプ ライバシーや居場所を確保するための工夫が要求される。

\section{4. 老人短期入所施設における利用者の生活実態}

\section{1 施設側の受け入れ体制}

初めてショートステイを利用する利用者に対して、利用前に利用 者の自宅を訪問し、心身状況や生活状況等を把握する面接（以下、 事前面接と表記する) を行なっているかについては、「必ず行なって いる」 21 施設、「可能な限り行なっている」 20 施設、「必要な場合に は行なっている」11 施設、「行なっていない」 5 施設である。さら に、事前面接を行っていない 5 施設を除いた 52 施設で、デイサービ ス等すでに各施設の関連サービスを利用しているが、ショートステ イは初めて利用するという利用者に対しても事前面接を行なうかに ついては、「必ず行なう」11 施設、「可能な限り行なう」8 施設、「必 要な場合には行なう」19施設、「あらためては行なわない」11 施設 であり、㮩極的に事前面接を実施する施設が大幅に减少する(表 2)。

事前面接の際、主に何を聞くかについて表 3 に示す項目を複数回 答でたずねたところ、「利用者の ADL や日常生活」が 48 施設、「在宅 での介護方法」が 34 施設、「利用者の生活歴」が 27 施設である。そ
の他に事前面接で承ねる内容としては、「利用者の病歴や医療状況」 「家族の要望」「利用者の要望」「主介護者が介護をする上で大切に 思っていること」利用者の馿染みの持ち物」「利用者の居室の状況」 等が多く举げられ、事前面接によって利用申請の紙面に現れてこな い事柄や、より詳細な状況の把握が行なわれている。

さらに事前面接の結果が、利用者が施設で利用する居室を決める 要因になるかについては「なる」が 48 施設、「ならない」が 3 施設 であり、事前面接を行なっている多くの施設で面接により利用居室 を決めていることがわかる。また、事前面接の結果が利用者の居室 や施設生活にいかされている事柄について表 3 に示す。居室に関し ては「ベッドか盢の選択」「ベッドの位置の変更」「利用者の性格や 症状に合わせて同室者を決定する」「机、テレビ等と、ベッドとの位 置関係を自宅同様に配置する」等が、施設生活に関しては「日中の 過ごし方を個々の利用者によって対応する」てでるる限り自宅での生 活のリズムに近づける」「できる限り自宅での介護方法を継続する」 等が多く举げられ、事前面接の結果が利用者の居室や施設生活、施 設でのケア方法に影響を与えていることがわかる。

利用者が短期間施設で生活するために行なうショートステイの 事前面接と、デイサービス等限られた時間のサービスを利用するた めに行なう事前面接とでは、施設側が留意すべき内容が異なる。し たがって、各施設の関連サービス利用有無に関わらず、ショートス テイ独自のプログラムをもって事前面接を実施することは、利用者 の状況を詳細に把握し、利用居室、施設生活、施設でのケア方法に 反映させる有効策の一つになり得る。

表2. 事前面接実施状況

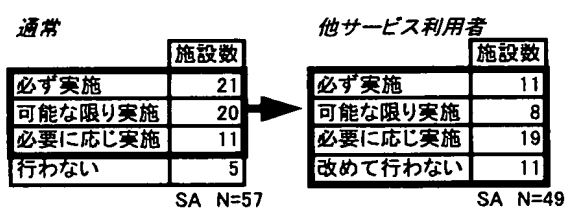

表3. 事前面接の内容と結果

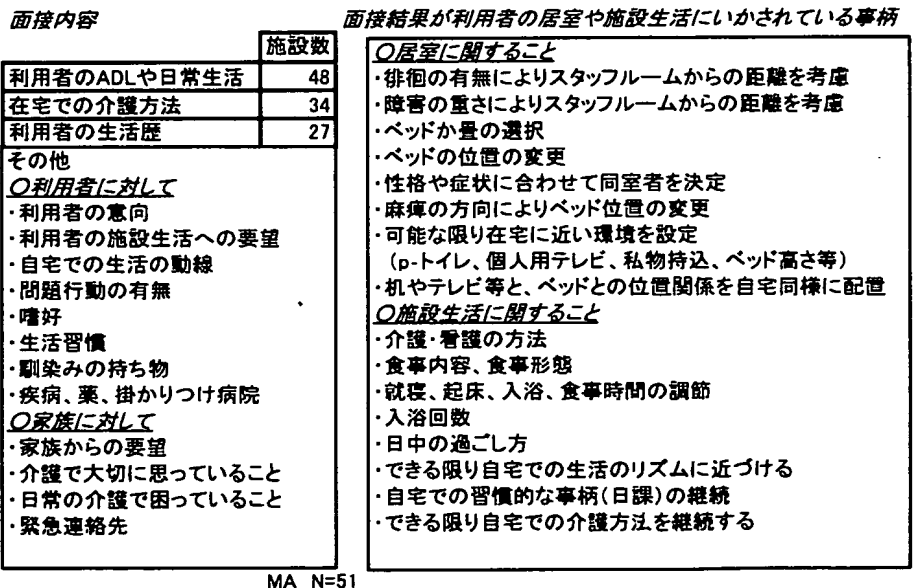

\section{2 利用者の日中の居場所}

利用者の日中の居場所として、居室と食堂、小規模な居場所、外 部空間をとりあげ、以下に考察する（表 4 ）。

\section{2.1 居室}

利用者の居室については、利用されている居室の種類と数につい 
ては表 1 の施設概要に示す通りであり、利用者に対して個室のみを 利用している施設は 57 施設中 4 施設である。個室以外の居室を利用 している 53 施設の場合で、各ベッドおよびベッド周りの間仕切りの 方法について複数回答で專ねたところ、「カーテン」が 43 施設、「家 具」が 19 施設、「つい立」が 7 施設であり、その他の方法としては 引き戸、壁、可動式の壁、ふすま、トイレ・洗面所が挙げられたが、 個々の利用者のプライバシーが守られにくい簡素な間仕切りを利用 している施設が多い。利用者は短期間であるが慣れない環境で生活 することで転居のストレスが生じる可能性があると思われ、施設側 は利用者のストレスを最小限にするための配慮が必要であり、利用 居室についてもエ夫が必要である。

\section{2.2 食堂}

57 施設のうち、利用者の食堂が一つしかない施設が 33 施設であ り、定員全てを一つの食堂に集結し食事する形態の施設が多い。

食事をすること以外の食堂の利用方法について表 4 に示す 5 項目 を複数回答で尋ねたところ、「レクリェーションの場所」が 47 施設、

「利用者の日中の居場所」が 45 施設、「家族の面会場所」が 31 施設 であり、食堂が食事以外の場として多く利用されている。食堂の設 置数と利用方法から、大きめの食堂が利用者の居場所になっている 施設が比較的多いことが伺える。

\subsection{3 小規模な居場所}

食堂とは別に、10 人以下の利用者が日中過ごせる小規模な居場所 があるかについては、「ある」が 37 施設、「ない」が 17 施設である。

「ある」と回答した施設で、その設置数については、「1ケ所」が 16 施設、「2 カ所」「 3 力所」がともに 7 施設、「 4 力所」が 3 施設、「5 カ所」が 2 施設であり、1 3 カ所の設置が多い。その居場所に置 いているものについて表 4 に示す 8 項目を複数回答で專ねたところ、 「テレビ」が 29 施設、「ソファー」が 26 施設、「植木鉢や花瓶」が 19 施設、「小机」が 17 施設、「ベンチ」が 14 施設であり、「部分的 な畳」「給湯セット」「自動販売機」が続く。その他の回答としては、 掘りごたつ、茶だんす、本棚・本・雑誌、マッサージ器等が挙げら れ、小規模な居場所には、家庭的な雲囲気のものやリラックスでき るものが置かれていることが同える。しかし小規模な居場所がない、 または設置数が少ない施設もあることから、各施設において、利用 者の生活拠点は自宅であることに配慮した、利用しやすい小規模な 居場所を積極的に設置することが望まれる。

\section{2.4 外部空間}

施設のべランダや庭・表玄関等の外部空間を自由に出入りできる かについては、ベランダについては「できる」が 13 施設、庭や表玄 関については、「できる」が 22 施設であり、ベランダ、庭・表玄関 ともに外部空間を自由に行き来できる施設は半数に満たない。また、 そのような外部空間に利用者が休㲘、交流できるようなべンチがあ るかについては、36施設が「ある」と回答している。利用者の外部 空間への自由な出入りができる施設数からみると、外部空間のベン チは無計画に置かれているケースがあるといえる。

利用者は自宅においては、本人や介護者、社会介護力、経済的問 題、住睘境等の要素で閉じこもりがちになり、特に、居室の閉じこ もりは人的要素が、住宅内の閉じこもりは住環境が大きく関わって いるといわれており ${ }^{15)}$ 、外部空間との関わりが少なくなると考えら れる。したがってショートステイ利用時に外部空間との関わりをも
てることは、居宅生活の不足部分を補え、心身面に良い影響が期待 できると考えられる。そのため各施設において、利用者が慣れない 環境でも転倒や混乱等がないよう配慮した、安全で快適に過ごせる 外部空間の整備、職員配置等の取り組みが求められる。

表4. 利用者の日中の居場所

\begin{tabular}{|c|c|c|c|}
\hline 日中の居婿所 & & 酶設数 & その他の回答 \\
\hline $\begin{array}{l}\text { 1. 居室 } \\
\text { 個室以外の居室の } \\
\text { 用仕切のの方法 } \\
\qquad \begin{array}{l}\text { MA } \\
N=57\end{array}\end{array}$ & $\begin{array}{l}\text { カーテン } \\
\text { 家具 } \\
\text { ついたて } \\
\text { 壁 }\end{array}$ & $\begin{array}{c}43 \\
19 \\
7 \\
0\end{array}$ & 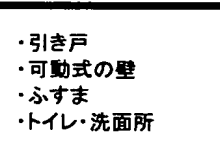 \\
\hline 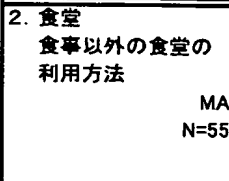 & 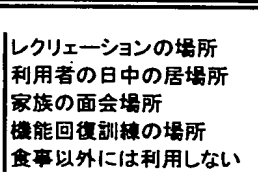 & $\begin{array}{l}47 \\
45 \\
31 \\
19 \\
3\end{array}$ & $\begin{array}{l}\text { ·入所受け入れの面接 } \\
\text { •スタフフ会境 }\end{array}$ \\
\hline 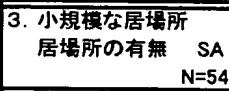 & \begin{tabular}{|l} 
ある \\
ない
\end{tabular} & $\begin{array}{l}37 \\
17\end{array}$ & \\
\hline $\begin{array}{l}\text { （居嵒所がある掹合） } \\
\text { 設贯数 } \\
\text { SA } \\
\text { N=35 }\end{array}$ & \begin{tabular}{|l} 
1ヶ所 \\
2ヶ所 \\
3ヶ所 \\
4ヶ所 \\
5 所 \\
\end{tabular} & $\begin{array}{l}16 \\
7 \\
7 \\
3 \\
2\end{array}$ & \\
\hline $\begin{array}{l}\text { (居嵒所がある埕合) } \\
\text { 世草いているもの } \\
\text { MA } \\
N=37\end{array}$ & 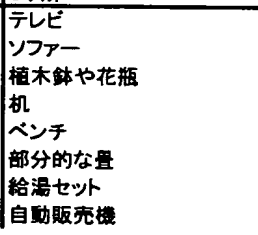 & $\begin{array}{l}29 \\
26 \\
19 \\
17 \\
14 \\
9 \\
9 \\
4\end{array}$ & 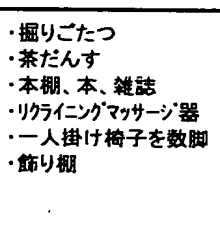 \\
\hline $\begin{array}{l}\text { 4. 外部空目 } \\
\text { ベランダの出入り } \\
\text { SA } \\
N=56\end{array}$ & $\begin{array}{l}\text { できる } \\
\text { 堛所により施㜔、一部可能 } \\
\text { できない } \\
\text { ベランダがない }\end{array}$ & $\begin{array}{c}13 \\
22 \\
13 \\
8\end{array}$ & \\
\hline $\begin{array}{r}\text { 庭、表玄関の出入り } \\
\mathrm{SA} \\
\mathrm{N}=56 \\
\end{array}$ & $\begin{array}{l}\text { できる } \\
\text { 塔所により族錠、一部可能 } \\
\text { てきない }\end{array}$ & $\begin{array}{l}22 \\
19 \\
15\end{array}$ & \\
\hline $\begin{array}{lr}\text { スンチの設贯 } & \text { SA } \\
\mathrm{N}=56\end{array}$ & $\begin{array}{l}\text { ある } \\
\text { ない }\end{array}$ & $\begin{array}{l}36 \\
20\end{array}$ & \\
\hline
\end{tabular}

\section{3 利用者の日中の活動}

利用者がショートステイ利用期間中に機能回復訓練ができるかに ついては、「できる」が 42 施設、「できない」が 13 施設である。機 能回復訓練ができる施設においてその頻度を对ねたところ、「利用者 が希望すればいつでもできる」が 31 施設、「週 5 回」が 5 施設、「週 1 回」「週 3 回」がともに 2 施設であり、積極的に機能回復訓練を取 り入れている施設が多い。

機能回復訓練を除いたレクリェーションの頻度については、毎日 行なっている施設が 20 施設あり、機能回復訓練同様、積極的に取り 入れている施設が多い。さらに、レクリェーションの時間以外に、 利用者が望めば自由に将棋や手芸ができるかについては、「できる」 が 47 施設、「できない」が 10 她設であり、大半の施設では自由な活 動を奨励している。

ショートステイ利用による利用者の ADL の低下は自宅における介

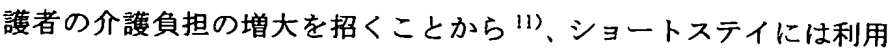
者の ADL が維持・向上されるケアが必要であり、機能回復訓練や、 レクリェーション、利用者の自由な活動を積極的に取り入れること は居宅介護の支援につながる。またショートステイを定期的に利用 する利用者が増加していることから、自由な活動は利用者間の交流、 利用者一職員間の交流をうみ、社会性が向上すると考えられる。 


\section{5. ショートステイ利用による居住噮境整解の契椎}

ショートステイ利用による居住嘌境への影響について表 $5 に$ 示す。 ショートステイを利用した家族から、施設でのケア方法や介護機 器を自宅にも迸入したいという要望があるかについては、「よくあ る」が 2 施設、「たまにある」が 34 施設、「あまりない」が 19 施設 である。また 35 施設は、施設から家族に対して、自宅でのケアや介 護機器導入について指導や助言をすることがある、としており、短 期入所施設が在宅介護支援センターやケアマネージャー的役割も担 っている。ケアや介護機器について施設から家族に対する助言・指 導の具体的な内容としては、ケアについては、「入浴・排泄・食事介 助の方法」「移乗の方法」「体位交換の方法」「立位・歩行訓練方法」 「食事形態・作り方」等が多く挙げられた。介護機器については、 「リハビリパンツ」「オムッ」「ポータブルトイレ」等の排泄補助に 関する機器、「リハビリシューズ」「杖」「歩行器」「車椅子」「電動車 椅子」等の移動補助に関する機器、その他「介護用ベッド」「エアマ ット」「入浴補助具」等が挙げられた。

利用者の自宅に専門性の高いケアや介護機器が導入されること は、施設と自宅の介護面の連繶性を作ることにつながり、利用者の 居宅生活および居宅介護の支援につながり得る。自宅へのケアおよ び介護機器の導入に関して、ショートステイ利用が導入のきっかけ になる場合もあり、老人短期入所施設はショートステイ利用期間中 以外にも居宅介護支援の一端を担え得るといえる。

しかし、家族からショートステイ職員に対して住宅改修の相談が あるかについては、「よくある」が 1 施設、「たまにある」が 21 施設、

「あまりないが 34 施設であり、ケアや介護機器の導入ほど相絘件 数がないことがわかる。またショートステイ職員から家族に対して も住宅改修に関する助言や指導が十分にされていない。

\section{表5. 居宅環境整備}

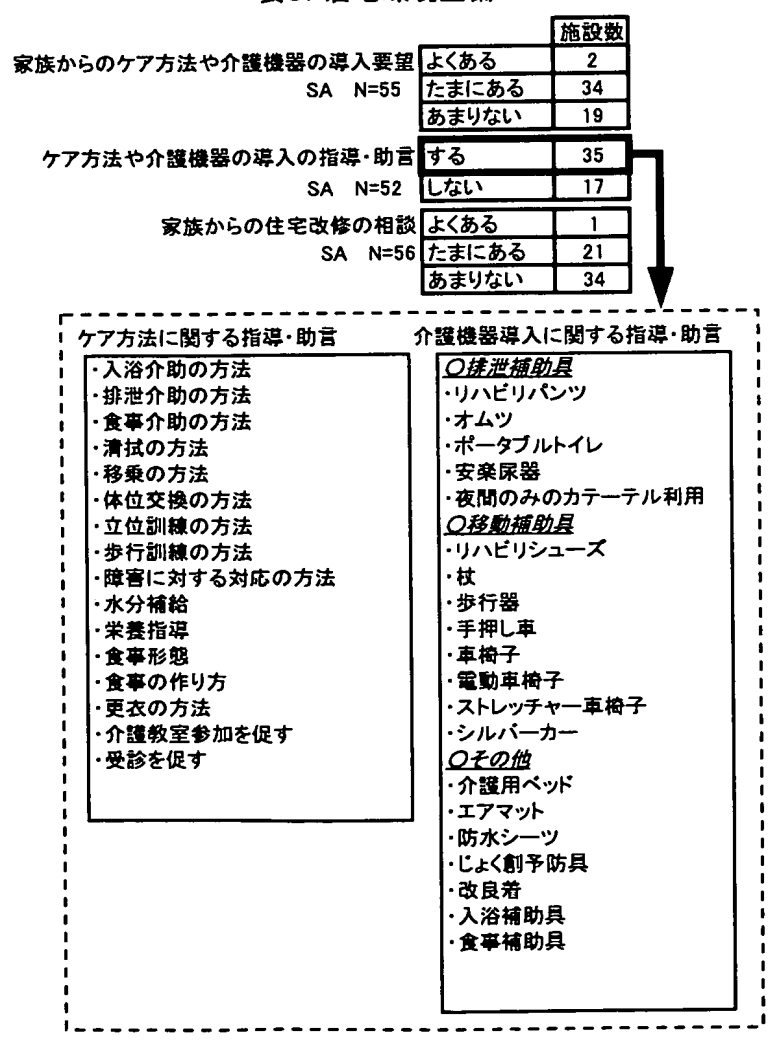

ケアや介護機器、住宅改修による居住罢境整備は、(1)事故等の予 防的効果、(2)高龄者の自立促進奻果、(3)居住者の行動変容の効果、 (4)サービスの提供方法の変化、(5)介謴費用の軽減効果があるといわ れており ${ }^{18)}$ 、居住睘境を整備することは利用者および介護者の生活 を継続する上で有奻である。現行の介護保険制度下では介護に関す る相談はケアマネージャーを通すことが多い。しかしショートステ イ職員は、ショートステイ利用期間中に昼夜通した利用者の心身状 㫛を詳細に把握することができるため、ショートステイ職員による ケアや介護機器、住宅改修の助言・指導は、個々の利用者に合った 助言や指導ができる、画一的な助言や指導に留まらない、という点 で非常に有効である。そのためショートステイ職員には、居住環境 整備に関する的確な助言・指導ができる知識が求められる。

\section{6.施設俱のショートステイ専門性の意裁}

ショートステイ利用者のみを入所対象とする短期入所施設だか らこそできることについて、各施設の考えを自由記述で求めたとこ ろ、その回答を大まかに 3 分類することができた。

1 つめは、瞕員が提供するケアに関する回答である。ケアを提供 する職員について、「ショートステイ専用の職員を配置することで、 在宅を支えるショートステイの意義を職員が理解しはじめた。」「シ ヨートステイ利用者と長期者入所者の要望が異なるため、利用者の 要望のみを考えることでスタッフのストレスが少なくなり、よいケ アの提供につながっている。」といった、特養の空きべッドを利用し てショートステイを行っていた施設がショートステイのみを独立さ せて短期入所施設に移行したことによる職員の意識や業務内容の変 化について回答が得られた。また、利用者に提供するケアについて、

「利用者や家族のニーズ、利用者の要介護度にあった幅広い対応が 可能になった。「在宅での生活リズムを守れる。」「在宅の介護方法 に近い個別処遇がたやすくできる。」「少人数対応で個人を大切にし たきめこまかいケアができる。」「居室等利用者の状況に合わせられ る。」「在宅生活に近い生活環境を個別に配慮できる。といった、サ 一ビス・施設空間両面の個別処遇の可能性について回答が得られた。

2つめは、職員から見た利用者の様子についての回答である。「シ ヨートステイのみで独立しているので、少人数で利用者間の交流が 図りやすい。」利用者が長期入所者に気兼ねしない「少人数で騒が しくないので痴呆の人が落ち着いている。といった、ショートステ イ利用者のみの独立した空間が利用者に与える影響について回答が 得られた。

3つめは、他サービスとの連搭についての回答である。「他部門 との連携がとりやすく、情報を共有して支援できる。」「在宅で必要 な他のサービスを一体的に、スムーズに提供できる。といった、建 物内または数地内に関連事業があることによるサービスの提供のし やすさについて回答が得られた。また、「ショートステイとデイサー ビスの利用者相互の交流が図れる。」デイサービスからショートス テイへの段階的利用で、職員と利用者間に良好な関係ができる。」と いった、一体的にサービスを提供することによる利用者への影響に ついても回答が得られた。さらに、「他サービスとの連管で家族状況 等の情報量も多くなる」「家族人情報提供がしやすい。「地域のニー ズに可能な限り応えられる。」といった、家族・地域との関係につい ても回答が得られた。 
各施設が考える短期入所施設のメリットを概観すると、ショート ステイ利用者のみの空間では、施設内で提供されるサービスであり ながら、ケア内容や生活リズム、居室環境等、利用者の居宅生活や 居宅介護を個別に配慮したサービスの提供が可能であることが示唆 される。同時にショートステイ職員には、その空間を有効活用でき るような専門性の高い意識や技術が求められる。

\section{7.まとめ}

本研究は、ショートステイの利用主体である要援護高齢者の生活 拠点は自宅であり、ショートステイは居宅介護の延長としてのサー ビスであるという観点に立って、ショートステイがどうあるべきか を考えようとするものである。本論では、老人短期入所施設のショ 一トステイ利用者のみの空間で展開されるケアの塞態を把握し、居 宅介護を支援する老人短期入所施設のあり方を検討する。

(1)初めてショートステイを利用する利用者への事前面接の実施状況 は様々であるが、その内容は利用者の状況把握に留まらない。各施 設の関連サービスの利用有無に関わらず、ショートステイ独自のプ ログラムをもって事前面接を実施することは、利用者の状況を詳細 に把握し、利用居室、施設生活、施設でのケア方法に反映させる有 効策の一つになり得る。

(2)近年、老人短期入所施設においても個室や二人部屋中心の施設が 増加傾向にあるが、個室以外の居室の場合にはカーテン等での簡素 な間仕切りの場合が多い。利用者は短期間であるが慣れない環境で 生活することで転居のストレスが発生すると思われ、施設側は利用 者のストレスを最小限にするための配慮が必要であり、利用居室に ついても工夫が必要である。

(3)老人短期入所施設では、利用者を 1 ヶ所の食堂に集結し、日中の 居場所としている施設が比較的多いが、食堂とは別に小規模な居場 所を設けている施設では、家庭的にその場を演出している。利用者 の生活执点が自宅であることに配慮した、利用しやすい小規模な居 場所を積極的に設置することが望まれる。

(4)老人短期入所施設では、利用者が外部空間を自由に行き来できる 施設が少ない。利用者は自宅においては様々な要因で閉じこもりが ちになるため、ショートステイ利用時に外部空間との関わりを持て ることは、心身面への効果が期待できる。したがって各施設におい て、利用者が慣れない環境でも転倒や混乱等がないよう配慮した外 部空間の整備、職員配置等の取り組みが求められる。

(5)老人短期入所施設では、機能回復訓練やレクリェーション、利用 者の自主的な活動を積極的に取り入れており、利用者の ADL 維持 • 向上や、利用者間の交流、利用者-職員間の交流による社会性の向上 が図られる機会が設けられている。

(6)利用者の自宅への専門性の高いケアおよび介護機器の導入に関し て、ショートステイ利用が導入のきっかけになる場合もあり、老人 短期入所施設はショートステイ利用期間中以外にも居宅介護支援の 一端を担え得るといえるが、住宅改修に関しては要望や助言・指導 が少ない。ケア面および環境面における施設環境と居宅睘境の連続 性をつくることは利用者の居宅生活および居宅介護の支援につなが り得る。数日間利用者をケアするショートステイ職員は個々の利用 者に合った助言や指導が可能であり、ショートステイ職員には、居 住環境整備に関する的確な助言・指導ができる知識が求められる。
(7)老人短期入所施設のショートステイ利用者のみの空間では、利用 者の居宅生活や居宅介護に配慮したサービス・施設空間両面の個別 処遇が可能である。同時にショートステイ職員には、その空間を有 勃活用できるような専門性の高い意識や技術が求められる。

\section{引用文蔽}

1) 坂田周一：『介護保険のしくみと利用法がわかる本』、成美堂出 版、東京都、130-131（2000）

2）齊藤芳徳、外山羲：高齡者居住施設における車イス使用者の移 動能力と生活展開に関する考察、日本建築学会計画系論文集、№.532、 pp149-156 (2000)

3）林悦子、小滝一正、林玉子：個室空間の住まい方特性-特別養護 老人ホームの個の空間に関する研究一、日本建築学会計画系論文集、 №.517、pp131-138 (1999)

4) 井上由起子、外山義、小滝一正、大原一興：高齢者居住施設に おける個別的介護に関する考察一住まいとしての特別養護老人ホー ムのあり方に関する研究 その 2-、日本建築学会計画系論文集、№ 508、pp83-90 (1998)

5 ）橘弘志、外山羲、高橋鹰志 : 特別養護老人ホーム入居者の個人 的領域形成と施設空間構成一個室型特別盖護老人ホームの空間構成 に関する研究 その 2-、日本建筑学会計画系論文集、№.523、 ppl63-170 (1999)

6) 山田明子、芦沢由紀、竹宮健司、上野淳 : 個室型特別養護老人 ホームの共用空間における入所者の生活行動に関する考察、日本建 築学会計画系論文集、No.546、pp105-112（2001）

7 ）渡邊昭彦、滝沢雄三：特別養護老人ホームの建築空間の活気・ 落ち着き空間検索行動実験による評価-特別養護老人ホームの活 気・落ち着きに関する研究 その2-日本建築学会計画系論文集、№. 513、pp101-110 (1998)

8 ）足立啓、亀屋恵三子、赤木徹也、橋本篤孝 : 特別養護老人ホー ムの段階的建替えによる入所者の環境移行と性格が行動に及ぼす影 響、日本建築学会計画系論文集、No.545、ppl43-149（2001）

9 ) 石井敏、長澤泰：痴呆性高龄者のグループホームにおける空間 利用の特性一フィンランドの疾呆・非痴呆グループホームにおける 比較分析を通して一、日本建築学会計画系論文集、NNo.537、pp93-99 (2000)

10）鈴木健二、外山義、三浦研：疾呆性高龄者のグループホームに おける入居者の生活の再編過程一疾呆性高齢者のケア環境のあり方 に関する研究 (1)、日本建築学会計画系論文集、№.546、pp121-126 (2001)

11）立松麻衣子、濟藤功子、西村一朗：在宅介護者の介護負担感上 ショートステイ利用効果、日本家政学会誌、52（7)、pp617-626 (2001)

12）立松麻衣子、齋藤功子、西村一朗：特別養護老人ホームにおけ るショートステイのための居室タイプに関する調査報告、日本建築 学会技術報告集、NNo.13、ppl69-174（2001）

13）立松麻衣子、齋藤功子、西村一朗：老人短期入所施設における 開設経歴と利用居室に関する調査報告、日本建築学会技術報告集、 No.14、印刷中

14）立松麻衣子、齋藤功子、西村一朗：要援護高龄者のショートス テイ利用効果、日本家政学会誌、53 (4)、印刷中

15）王青、筧淳夫、長澤泰 : 在宅療養高龄者の生活領域に関する考 察一高路者の閉じこもり現象について一、日本建筑学会計画系論文 集、Na.546、pp91-96 (2001)

16）児玉桂子 : 『高齢者居住環境の評価と計画』、中央法規、東京都、 16-17 (1998)

[2001年10月17日原稿受理２002年 2 月18日採用決定］ 